\title{
FUMIGANT TOXICITY OF SOME ESSENTIAL OILS ON ADULTS OF SOME STORED-PRODUCT PESTS
}

\author{
Mohammad Mahmoudvand ${ }^{1,2 *}$, Habib Abbasipour ${ }^{1}$, Moslem Basij ${ }^{1}$, Mohammad Hossein Hosseinpour ${ }^{1}$,
} Fahimeh Rastegar ${ }^{1}$, and Mohammad Bagher Nasiri ${ }^{1}$

\begin{abstract}
Plant materials with insecticidal properties have been traditionally used for generations in some parts of the world. In this study, fumigant toxicity of some essential oils extracted from Rosmarinus officinalis L., Mentha pulegium L., Zataria multiflora, and Citrus sinensis (L.) Osbeck var. hamlin on adults of stored-product pests, including Tribolium castaneum, Sitophilus granarius, Callosobruchus maculatus, and Plodia interpunctella were investigated. Pure essential oils were used in glass vials for the bioassay. $\mathrm{LC}_{50}$ values of Citrus sinensis var. hamlin against $T$. castaneum, S. granarius, and C. maculatus were 391.28, 367.75, and $223.48 \mu \mathrm{L} \mathrm{L}^{-1}$ air after $24 \mathrm{~h}, 362.40,20.45$, and $207.17 \mu \mathrm{L} \mathrm{L}^{-1}$ air after $48 \mathrm{~h}$, respectively. Furthermore, $\mathrm{LC}_{50}$ values of the fumigant test of $C$. sinensis and $M$. pulegium essential oils against $S$. granarius were 0.038 and $367.75 \mu \mathrm{L} \mathrm{L}^{-1}$ air after $24 \mathrm{~h}, 0.025$ and $320.45 \mu \mathrm{L} \mathrm{L}^{-1}$ air after $48 \mathrm{~h}$, respectively. On the other hand, $\mathrm{LC}_{50}$ values of $R$. officinalis and Z. multiflora on P. interpunctella moths were 0.93 and $1.75 \mu \mathrm{L} \mathrm{L}^{-1}$ after $24 \mathrm{~h}$. Results showed that among tested essential oils, $C$. sinensis var. hamlin had good fumigant toxicity on $T$. castaneum, S. granarius, and C. maculatus. In addition, M. pulegium essential oil was stronger than $C$. sinensis var. hamlin on S. granarius. Results also indicated that both Z. multiflora and R. officinalis had fumigant toxicity on $P$. interpunctella adults. In summary, results indicated that these essential oils have good fumigant toxicity on stored-product pests.
\end{abstract}

Key words: Fumigant toxicity, Citrus sinensis var. hamlin, Zataria multiflora, Plodia interpunctella.

\section{INTRODUCTION}

Protecting crops against agricultural pests is known to depend on the use of synthetic chemical pesticides (Isman, 2000). Broad-spectrum insecticides have been reported to cause development of resistance in insect populations (Bughio and Wilkins, 2004). In this regard, natural products are generally preferred because of their innate biodegradability and less harmful compounds affecting non-target organisms (Prabakar and Jebanesan, 2004). Plants have acquired effective defense mechanisms that ensure their survival under adverse environmental factors. In addition to morphological mechanisms, plants have also developed chemical defense mechanisms towards organisms such as insects that affect biochemical and physiological functions (Prakash and Rao, 1997).

\footnotetext{
${ }^{1}$ Shahed University, Faculty of Agricultural Sciences, Tehran, Iran. *Corresponding author (msco_1381@yahoo.com).

${ }^{2}$ Islamic Azad University, Qom branch, Young Researchers Club, Qom, Iran.

Received: 4 September 2010

Accepted: 7 November 2010.
}

Essential oils are usually extracted from various parts of the plant (Daferera et al., 2000; Isman, 2000). In some Asian and African countries, essential oils are traditionally used through fumigant or contact action to protect grains against storage pests, a suitable method to preserve products stored in warehouses and on small farms (Shaaya et al., 1997). Zataria multiflora Boiss. (Lamiaceae), which is locally known as Avishan-e-Shirazi, is an Iranian native plant that grows only in Iran, Pakistan, and Afghanistan (Mozzaffarian, 1998; Ali et al., 2000). Rosemary, Rosmarinus officinalis L. (Lamiaceae), an evergreen shrub with linear leathery leaves grows to a maximum height of $2 \mathrm{~m}$ in the Mediterranean region. Rosemary flowers are pale to mid-blue and 10-12 mm long (Blamey and Grey-Wilson, 1998). Mentha pulegium L. (Lamiaceae) is used as insect repellent in Iran because of its antispasmodic, diaphoretic, and anti-inflammatory properties (Marderosian, 2001). Sweet orange, Citrus sinensis L. (Rotaceae), is one of the medicinal plants prescribed as traditional medicine to treat diverse illnesses (Intekhab and Aslam, 2009). It has been used as insect repellent, antibacterial, and larvicide (Han, 1998). The essential oil of $C$. sinensis also has 
fumigant toxicity against Aedes aegypti L. mosquitoes (Omomouwajo et al., 2005).

One of the major storage pests of cowpea (Vigna sinensis L.) is Callosobruchus maculatus (F.) (Coleoptera: Bruchidae) (Epidi et al., 2008), which is an important insect pest of many grains, such as chickpea (Cicer arietinum L.), lentil (Lens culinaris Medik.), and soybean (Glycine max L.) (Mahfuz and Khalequzzaman, 2007). In addition, Tribolium castaneum Herbst (Coleoptera: Tenebrionidae) is also a major storage pest that prefers grain products such as flour (Lecato, 1976; Campbell and Runnion, 2003). Granary weevil, Sitophilus granarius (L.), is ranked among the important stored grain pests. It was a primary pest in the past (Kucerova et al., 2003). Indian meal moth, Plodia interpunctella (Hübner) (Lepidoptera: Pyralidae), is a worldwide and major storedproduct pest that infests a wide range of stored products, including nuts, beans, processed foods, and dried fruits (Simmons and Nelson, 1975; Lecato, 1976).

In this study, the fumigant toxicity of cortex powder of a variety of $C$. sinensis, $C$. sinensis var. hamlin on adults of three important pests, T. castaneum, Sitophilus granarius, and C. maculatus after 24 and $48 \mathrm{~h}$ was investigated. The toxicity of $C$. sinensis var. hamlin and M. pulegium against adults of Sitophilus granarius after 24 and $48 \mathrm{~h}$ was also compared. In addition, toxicity of $R$. officinalis and $Z$. multiflora essential oils against $P$. interpunctella moths after $24 \mathrm{~h}$ was explored, and $\mathrm{LC}_{50}$ values of these essential oils were calculated. Insect mortality was also recorded for the examined insects at various time periods $(3,6,9,12$, and $48 \mathrm{~h})$.

\section{MATERIALS AND METHODS}

\section{Essential oil extraction}

Aerial parts of $R$. officinalis and $M$. pulegium were collected from the garden of the Medicinal Plants Research Center of Shahed University, Tehran, in July 2009. Leaves of Z. multiflora were collected in the Nour-Abad region (Fars Province) in May 2009. After collecting fruits of $C$. sinensis var. hamlin in the Jiroft region (Kerman Province) in December 2008, their cortex powder was used to extract essential oils. All the collected plant materials were shade-dried at room temperature. Dried materials were then subjected to hydrodistillation with a Clevenger-type distiller (Cavalcanti et al., 2004). To extract essential oils by distillation, $50 \mathrm{~g}$ of air-dried plant material was put into water $(1: 12 \mathrm{w} / \mathrm{v})$ for $4 \mathrm{~h}$. Extracted essential oils were dried via anhydrous sodium sulfate and stored at $4{ }^{\circ} \mathrm{C}$ in the dark. Pure essential oils were employed in all the tests.

\section{Insect rearing}

The insect colonies were reared at $27 \pm 1{ }^{\circ} \mathrm{C}, 65 \pm 5 \%$
RH, and dark conditions. Flour, wheat (Triticum aestivum L.) grains, mung bean (Vigna radiata (L.) R. Wilczek) grains, and pistachio (Pistacia vera L.) were employed to rear $T$. castaneum, $S$. granarius, $C$. maculatus, and $P$. interpunctella, respectively.

\section{Fumigant bioassay of coleopteran pests}

The fumigant toxicity of essential oils on $T$. castaneum, $S$. granarius, and C. maculatus were tested in glass vials $(70 \mathrm{~mL})$ in which 10 adult insects (1- to 7-d-old) were released. Filter paper disks (Whatman $\mathrm{N}^{\circ} 1$ ) were cut into $2-\mathrm{cm}$ diameter pieces and fixed under the glass vial screw caps. Filter papers were impregnated with a series of concentrations of each essential oil. Treated insects were transferred to untreated vials after $24 \mathrm{~h}$. Four replicates were run for each concentration and for the control groups. Numbers of dead and live insects were also counted after $3,6,9,12,24$, and $48 \mathrm{~h}$ from the start of exposure. The control did not show any mortality.

\section{Fumigant bioassay of $\boldsymbol{P}$. interpunctella moths}

These experiments were similar to those of coleopteran pests although in these tests vials were $600 \mathrm{~mL}$ and moths were 1-d-old. In these experiments, mortality was also recorded after $3,6,9,12$, and $24 \mathrm{~h}$ from the start of exposure.

\section{Statistical analysis}

The 50 and $90 \%$ lethal concentration $\left(\mathrm{LC}_{50}\right.$ and $\left.\mathrm{LC}_{90}\right)$ values were assessed by Probit analysis (Finney, 1971) with SAS software (SAS Institute, 1997).

\section{RESULTS}

\section{Fumigant toxicity on coleopteran pests}

Tables 1 and 2 show $\mathrm{LC}_{50}$ and $\mathrm{LC}_{90}$ values of $C$. sinensis var. hamlin essential oils on T. castaneum, S. granarius, and C. maculatus after 24 and $48 \mathrm{~h}$. Results indicated that C. maculatus is more susceptible than T. castaneum and $S$. granarius. $\mathrm{LC}_{50}$ values of $C$. sinensis var. hamlin on T. castaneum, $S$. granarius, and C. maculatus after $24 \mathrm{~h}$ were $391.28,367.75$, and $223.48 \mu \mathrm{L} \mathrm{L}^{-1}$ air, respectively. After $48 \mathrm{~h}, \mathrm{LC}_{50}$ values were lower than those measured after $24 \mathrm{~h}$, but this decrease was not significant. Values of $\mathrm{LC}_{50}$ after $48 \mathrm{~h}$ were $362.40,320.45$, and $207.17 \mu \mathrm{L} \mathrm{L}^{-1}$ air. Tables 3 and 4 compare $C$. sinensis var. hamlin and $M$. pulegium for their fumigant toxicity on $S$. granarius after 24 and 48 h. Data indicate that $\mathrm{LC}_{50}$ values of $M$. pulegium were much higher than $C$. sinensis var. hamlin. Values of $\mathrm{LC}_{50}$ for $C$. sinensis var. hamlin and M. pulegium were 0.038 and $367.75 \mu \mathrm{L} \mathrm{L}^{-1}$ air after $24 \mathrm{~h}, 0.025$ and 320.45 $\mu \mathrm{L} \mathrm{L}^{-1}$ air after $48 \mathrm{~h}$, respectively.

In addition, Figures 1 to 3 show mortality trends for T. castaneum, S. granarius, and C. maculatus at different 
concentrations and times after exposure to $C$. sinensis var. Hamlin. In Figure 4, the mortality trend of S. granarius is depicted at all concentrations after treatment with $M$. pulegium in different time periods. According to Figures 1 to 4 , the highest mortality in coleopteran pests occurred after $12 \mathrm{~h}$.

Table 1. Fumigant toxicity of Citrus sinensis var. hamlin essential oil against three coleopteran stored-products pests after 24 h.

\begin{tabular}{|c|c|c|c|c|c|c|}
\hline & $\mathbf{n}^{1}$ & $D^{2} \mathbf{f}^{2}$ & $\mathrm{LC}_{50}{ }^{3}$ & $\mathrm{LC}_{90}{ }^{4}$ & Slope $\pm \mathrm{SE}^{5}$ & $\chi^{2}$ \\
\hline & & & \multicolumn{2}{|c|}{$\mu \mathrm{L} \mathrm{L}^{-1}$ air $\longrightarrow$} & & \\
\hline Tribolium castaneum & 200 & 3 & $391.28(375.77-403.55)$ & $482.70(458.92-529.71)$ & $14.05 \pm 2.38$ & 4.37 \\
\hline Sitophilus granarius & 240 & 4 & $367.75(351.20-384.44)$ & $508.91(470.60-579.52)$ & $9.08 \pm 1.27$ & 2.52 \\
\hline Callosobruchus maculatus & 200 & 3 & $223.48(209.49-237.29)$ & $332.80(301.94-391.07)$ & $7.41 \pm 1.06$ & 1.70 \\
\hline
\end{tabular}

\footnotetext{
${ }^{1}$ Number of individuals.

${ }^{2}$ Degrees of freedom.

${ }^{3}$ Chemical concentration that kills $50 \%$ of a sample population.

${ }^{4}$ Chemical concentration that kills $90 \%$ of a sample population.

${ }^{5}$ Standard error.
}

Table 2. Fumigant toxicity of Citrus sinensis var. hamlin essential oil against three coleopteran stored-products pests after $48 \mathrm{~h}$.

\begin{tabular}{|c|c|c|c|c|c|c|}
\hline & $\mathbf{n}^{1}$ & $\mathrm{Df}^{2}$ & $\mathrm{LC}_{50}{ }^{3}$ & $\mathrm{LC}_{90}{ }^{4}$ & Slope $\pm \mathrm{SE}^{5}$ & $\chi^{2}$ \\
\hline & & & \multicolumn{2}{|c|}{$\longrightarrow \mu \mathrm{L} \mathrm{L}^{-1}$ air } & & \\
\hline Tribolium castaneum & 200 & 3 & $362.40(339.43-376.45)$ & $442.69(425.56-474.49)$ & $14.74 \pm 2.66$ & 2.62 \\
\hline Sitophilus granarius & 240 & 4 & $320.45(297.86-337.37)$ & $456.48(424.91-515.28)$ & $8.33 \pm 1.28$ & 2.34 \\
\hline Callosobruchus maculatus & 200 & 3 & 207.17 (196.57-217.12) & $275.83(258.34-304.68)$ & $10.30 \pm 1.33$ & 7.76 \\
\hline
\end{tabular}

${ }^{1}$ Number of individuals.

${ }^{2}$ Degrees of freedom.

${ }^{3}$ Chemical concentration that kills $50 \%$ of a sample population.

${ }^{4}$ Chemical concentration that kills $90 \%$ of a sample population.

${ }^{5}$ Standard error.

Table 3. Comparing the fumigant toxicity of Citrus sinensis var. hamlin and Mentha pulegium essential oils against Sitophilus granarius after $24 \mathrm{~h}$.

\begin{tabular}{|c|c|c|c|c|c|c|}
\hline & $\mathbf{n}^{1}$ & $\mathbf{D f}^{2}$ & $\mathrm{LC}_{50}{ }^{3}$ & $\mathrm{LC}_{90}{ }^{4}$ & Slope $\pm \mathrm{SE}^{5}$ & $\chi^{2}$ \\
\hline & & & \multicolumn{2}{|c|}{$\mu \mathrm{L} \mathrm{L}^{-1}$ air } & & \\
\hline Mentha pulegium & 240 & 4 & $0.038(0.0311-0.046)$ & $0.137(0.105-0.209)$ & $2.34 \pm 0.32$ & 1.86 \\
\hline Citrus sinensis & 240 & 4 & $367.75(351.20-384.44)$ & $508.91(470.60-579.52)$ & $9.08 \pm 1.27$ & 2.52 \\
\hline
\end{tabular}

${ }^{1}$ Number of individuals.

${ }^{2}$ Degrees of freedom.

${ }^{3}$ Chemical concentration that kills $50 \%$ of a sample population.

${ }^{4}$ Chemical concentration that kills $90 \%$ of a sample population.

${ }^{5}$ Standard error.

Table 4. Comparing the fumigant toxicity of Citrus sinensis var. hamlin and Mentha pulegium essential oils against Sitophilus granarius after $48 \mathrm{~h}$.

\begin{tabular}{|c|c|c|c|c|c|c|}
\hline & $\mathbf{n}^{1}$ & $\mathbf{D f}^{2}$ & $\mathrm{LC}_{50}{ }^{3}$ & $\mathrm{LC}_{90}{ }^{4}$ & Slope $\pm \mathrm{SE}^{5}$ & $\chi^{2}$ \\
\hline & & & \multicolumn{2}{|c|}{$\longrightarrow \mu \mathrm{L} \mathrm{L}^{-1}$ air } & & \\
\hline Mentha pulegium & 240 & 4 & $0.025(0.018-0.031)$ & $0.091(0.0722-0.136)$ & $2.29 \pm 0.36$ & 4.01 \\
\hline Citrus sinensis & 240 & 4 & $320.45(297.86-337.37)$ & $456.48(424.91-515.28)$ & $8.33 \pm 1.28$ & 2.34 \\
\hline
\end{tabular}

\footnotetext{
${ }^{1}$ Number of individuals.

${ }^{2}$ Degrees of freedom.

${ }^{3}$ Chemical concentration that kills $50 \%$ of a sample population.

${ }^{4}$ Chemical concentration that kills $90 \%$ of a sample population.

${ }^{5}$ Standard error.
} 


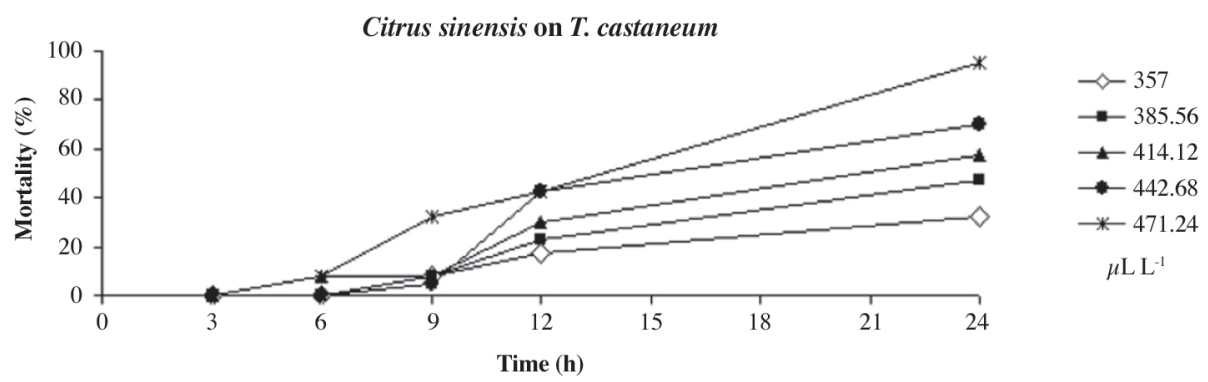

Figure 1. Mortality of Tribolium castaneum adults exposed to Citrus sinensis var. hamlin essential oil at different concentrations and times.

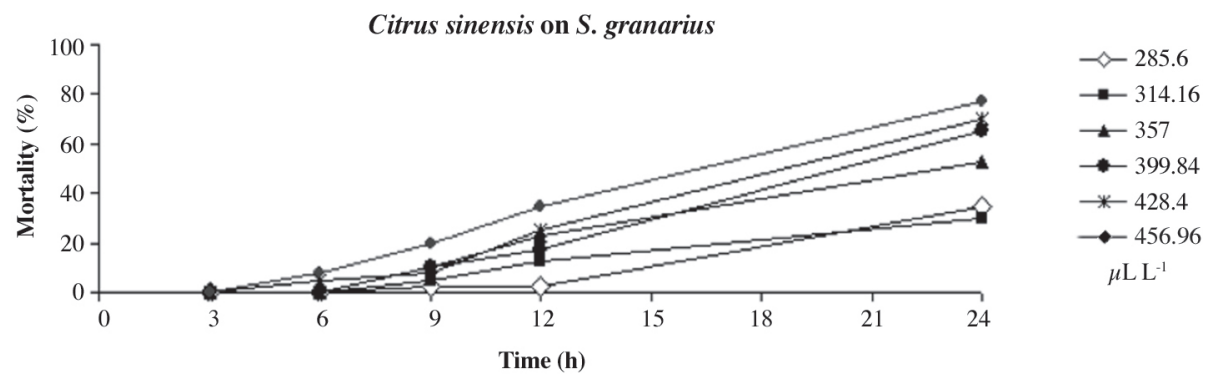

Figure 2. Mortality of Sitophilus granarius adults exposed to Citrus sinensis var. hamlin essential oil at different concentrations and times.

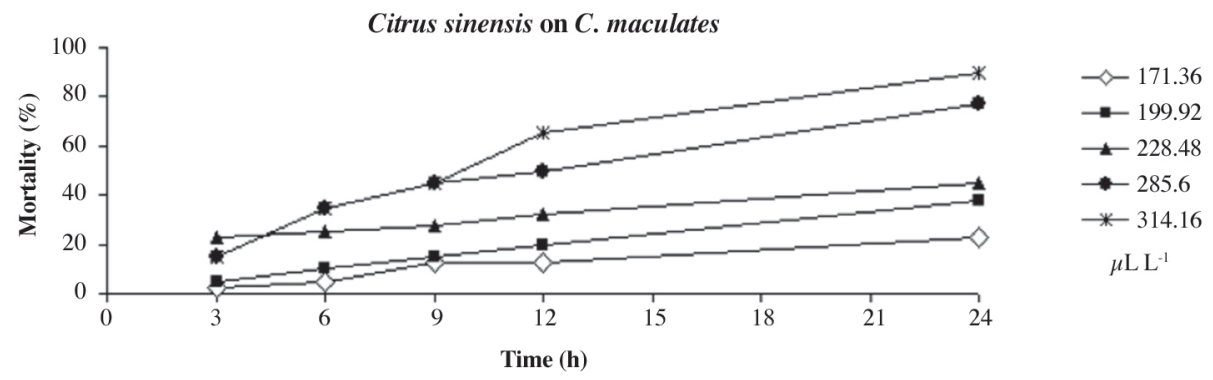

Figure 3. Mortality of Callosobruchus maculatus adults exposed to Citrus sinensis var. hamlin essential oil at different concentrations and times.

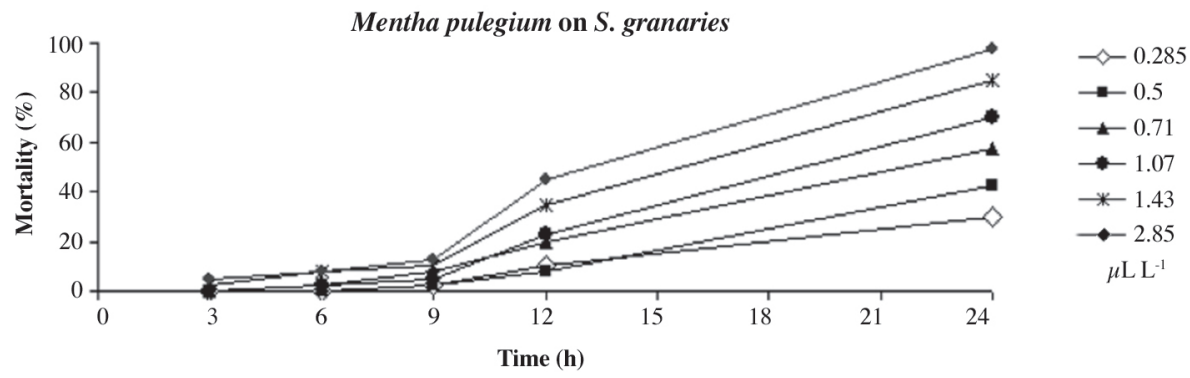

Figure 4. Mortality of Sitophilus granarius adults exposed to Mentha pulegium essential oil at different concentrations and times.

\section{Fumigant toxicity on $P$. interpunctella moths}

Table 5 shows the effects of fumigating $R$. officinalis and $Z$. multiflora essential oils on $P$. interpunctella moths after $24 \mathrm{~h}$. Comparing $\mathrm{LC}_{50}$ values, it was observed that both $R$. officinalis and Z. multiflora had fumigant toxicity on $P$. interpunctella moths, but $R$. officinalis was more toxic than Z. multiflora. $\mathrm{LC}_{50}$ values of $R$. officinalis and Z. multiflora were 0.93 and $1.75 \mu \mathrm{L} \mathrm{L}^{-1}$ air. Figures 5 and 6 show the mortality rates of $P$. interpunctella in different concentrations and time periods after exposure to $R$. officinalis and Z. multiflora. The mortality trend of $P$. interpunctella increased with both essential oils after $12 \mathrm{~h}$. 
Table 5. Fumigant toxicity of Rosmarinus officinalis and Zataria multiflora essential oils against Plodia interpunctella moths after $24 \mathrm{~h}$.

\begin{tabular}{|c|c|c|c|c|c|c|}
\hline & $\mathrm{n}^{1}$ & $\mathrm{Df}^{2}$ & $\mathrm{LC}_{50}{ }^{3}$ & $\mathrm{LC}_{90}{ }^{4}$ & Slope $\pm \mathrm{SE}^{5}$ & $\chi^{2}$ \\
\hline & & & \multicolumn{2}{|c|}{$\mu \mathrm{L} \mathrm{L}^{-1}$ air } & & \\
\hline Rosmarinus officinalis & 200 & 3 & $0.93(0.71-1.21)$ & $6.33(3.47-27.19)$ & $1.54 \pm 0.33$ & 4.90 \\
\hline Zataria multiflora & 240 & 4 & $1.75(1.28-2.45)$ & $24.26(11.40-114.13)$ & $1.12 \pm 0.20$ & 3.40 \\
\hline
\end{tabular}

${ }^{1}$ Number of individuals.

${ }^{2}$ Degrees of freedom.

${ }^{3}$ Chemical concentration that kills $50 \%$ of a sample population.

${ }^{4}$ Chemical concentration that kills $90 \%$ of a sample population.

${ }^{5}$ Standard error.

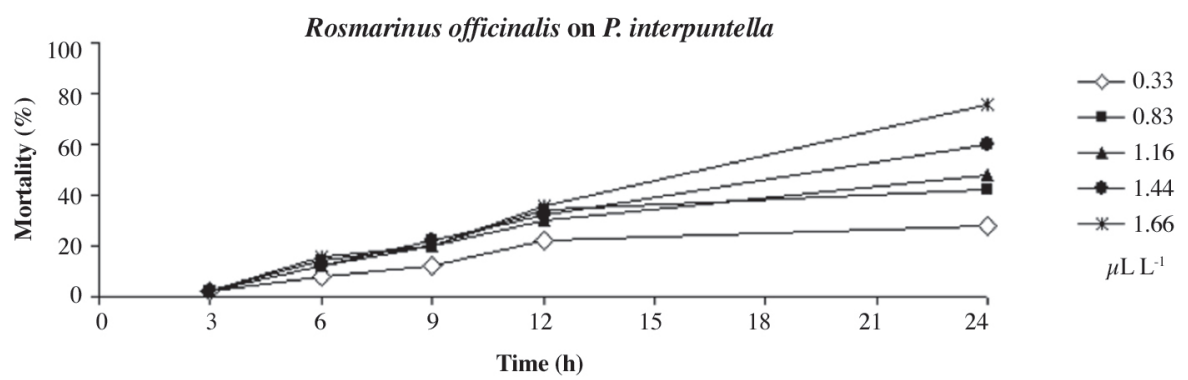

Figure 5. Mortality of Plodia interpunctella moths exposed to Rosmarinus officinalis essential oil in different concentrations and times.

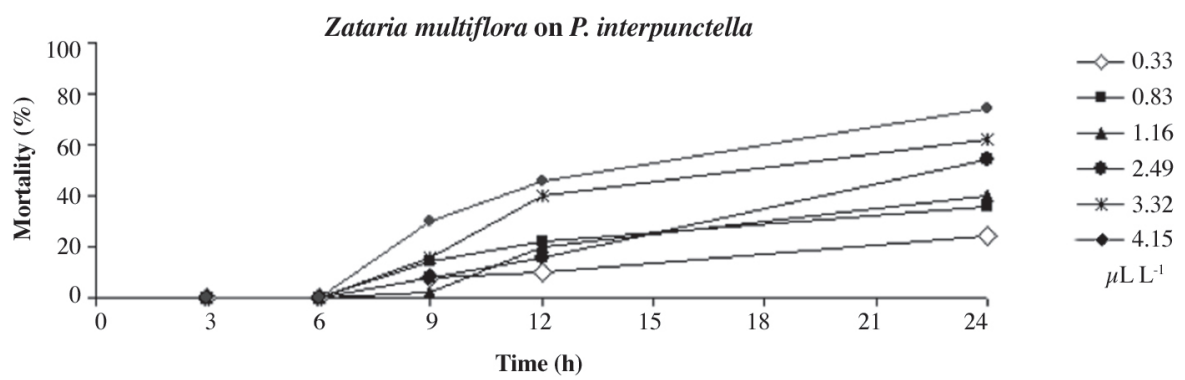

Figure 6. Mortality of Plodia interpunctella moths exposed to Zataria multiflora essential oil in different concentrations and times.

\section{DISCUSSION}

Natural compounds from plants could be efficient alternatives to conventional fumigants because of their low toxicity to mammals, fast degradability properties, and regional availability (Rajendran and Sriranjini, 2008). Our results on fumigant toxicity of $C$. sinensis var. Hamlin on T. castaneum, S. granarius, and C. maculatus indicated that this essential oil had good toxicity on these pests by fumigation. Among the examined pests, C. maculatus was the most sensitive. On the other hand, comparing $\mathrm{LC}_{50}$ values of $C$. sinensis var. hamlin and M. pulegium on $S$. granarius, it was found that $C$. sinensis var. hamlin was more toxic than $C$. sinensis. In accordance with this study, Mahmoudvand et al. (2011) reported that M. pulegium essential oil was more toxic than Lippia citrodora Kunth
(Verbenaceae), R. officinalis, and Juniperus sabina (Pinaceae) on C. maculatus. Our results also showed that $R$. officinalis and Z. multiflora had fumigant toxicity against $P$. interpunctella moths after $24 \mathrm{~h}$. $\mathrm{LC}_{50}$ value of Z. multiflora on P. interpunctella was $1.75 \mu \mathrm{L} \mathrm{L}^{-1}$ air. Our study is the first to report the insecticidal activity and fumigant toxicity of $Z$. multiflora, which is native to Iran (Mozzaffarian, 1998), on a moth. Rastegar et al. (2010) indicated that by treating $C$. maculatus with $Z$. multiflora essential oil $\mathrm{LC}_{50}$ values were $8.81 \mu \mathrm{L} \mathrm{L}^{-1}$ after $24 \mathrm{~h}$. In another study, Mahmoudvand et al. (2011) showed that the $\mathrm{LC}_{50}$ value of fumigant toxicity of $R$. officinalis on $C$. maculatus was $46.81 \mu \mathrm{L} \mathrm{L}^{-1}$ air. These results indicated that moths are more susceptible than coleoptera and low essential oil concentrations are more effective on moths than on beetles. Similar to this study, Shojaaddini et al. 
(2008) assessed the effect of Carum copticum C.B. Clarke (Apiaceae) essential oil on eggs, larvae, pupae, and adults of $P$. interpunctella. They reported that adult stage was more susceptible than other growth stages. In this study, $\mathrm{LC}_{50}$ values at $48 \mathrm{~h}$ were lower than those at $24 \mathrm{~h}$. On the other hand, results indicated that the high rate of mortality occurred between 12 and $24 \mathrm{~h}$, although mortality increased after $24 \mathrm{~h}$.

This showed that the effects of current essential oils were not reversible. To these authors' knowledge, there are no studies about fumigant effects of essential oil of this variety (hamlin) of $C$. sinensis on insects. Zewde and Jembere (2010) studied the effect of $C$. sinensis essential oil on Zabrotes subfasciatus $\mathrm{L}$. and showed that $C$. sinensis had contact toxicity on this insect pest.

Results of this study clearly illustrated that insects varied in their susceptibility to different essential oils, which probably refers to the insecticidal ability of their active constituents; however, there is no difference between the time of high mortality for all essential oils and insects.

\section{CONCLUSIONS}

In conclusion, essential oil of $C$. sinensis var. hamlin cortex powder had fumigant toxicity on $T$. castaneum, $S$. granarius, and $C$. maculatus, and susceptibility of $C$. maculatus was the highest. Fumigant toxicity effect of $M$. pulegium was also higher than $C$. sinensis var. hamlin on $S$. granarius. Bioassay tests also indicated that the Iranian native plant, Z. multiflora, is a good choice for a fumigant toxicity test on $P$. interpunctella, and its toxicity was lower than $R$. officinalis. All essential oils examined in this study exerted good toxicity on stored-product pests and can be used to manage these pests.

\section{ACKNOWLEDGEMENT}

We thank the members of the Laboratory of Entomology and the Department of Plant Protection of Shahed University, Tehran, Iran, for their assistance.

\section{RESUMEN}

Toxicidad fumigante de algunos aceites esenciales sobre adultos de algunas plagas de productos almacenados. Materiales vegetales con propiedades insecticidas han sido usados tradicionalmente por generaciones en algunas partes del mundo. En este estudio se estudió la toxicidad fumigante de algunos aceites esenciales extraídos desde Rosmarinus officinalis L., Mentha pulegium L., Zataria multiflora y Citrus sinensis (L.) Osbeck var. hamlin sobre adultos de plagas de productos almacenados, incluyendo Tribolium castaneum, Sitophilus granarius, Callosobruchus maculatus y Plodia interpunctella. Para los bioensayos se usaron aceites esenciales puros en frascos de vidrio. Los valores de $\mathrm{LC}_{50}$ de $C$. sinensis var. hamlin contra $T$. castaneum, $S$. granarius y $C$. maculatus fueron 391,$28 ; 367,75$ y 223,48 después de $24 \mathrm{~h}$ y 362,$40 ; 20,45$ y $207,17 \mu \mathrm{L} \mathrm{L}^{-1}$ aire después de $48 \mathrm{~h}$, respectivamente. Además, los valores de $\mathrm{LC}_{50}$ de la prueba fumigante del aceite esencial de $C$. sinensis y M. pulegium contra $S$. granarius después de 24 h fueron 0,038 y 367,75 $\mu \mathrm{L} \mathrm{L}^{-1}$ aire y fueron 0,025 y 320,45 después de $48 \mathrm{~h}$, respectivamente. Por otra parte, los valores de $\mathrm{LC}_{50}$ de $R$. officinalis y Z. multiflora en polillas de $P$. interpunctella después de $24 \mathrm{~h}$ fueron 0,93 y $1,75 \mu \mathrm{L} \mathrm{L}^{-1}$. Los resultados mostraron que entre los aceites esenciales, $C$. sinensis var. hamlin tuvo una buena toxicidad fumigante sobre $T$. castaneum, S. granarius, C. maculatus. Además, el aceite esencial de $M$. pulegium fue más fuerte que $C$. sinensis var. hamlin sobre $S$. granarius. Los resultados además indicaron que Z. multiflora and R. officinalis tuvieron toxicidad fumigante sobre adultos de P. interpunctella. En conclusión, los resultados indicaron que estos aceites esenciales tienen buena toxicidad fumigante sobre plagas de productos almacenados.

Palabras clave: toxicidad fumigante, Citrus sinensis var. hamlin, Zataria multiflora, Plodia interpunctella.

\section{LITERATURE CITED}

Ali, M.S., M. Saleem, Z. Ali, and V.U. Ahinad. 2000. Chemistry of Zataria multiflora (Lamiaceae). Phytochemistry 55:933-936.

Blamey, M., and C. Grey-Wilson. 1998. Mediterranean wild flowers. 560 p. Harper Collins, London, UK.

Bughio, F.M., and R.M. Wilkins. 2004. Influence of malathion resistance status on survival and growth of Tribolium castaneum (Coleoptera: Tenebrionidae), when fed on flour from insect-resistant and susceptible grain rice cultivars. Journal of Stored Products Research 40:65-75.

Campbell, J.F., and C. Runnion. 2003. Patch exploitation by female red flour beetles, Tribolium castaneum. $8 \mathrm{p}$. Journal of Insect Science 3:20.

Cavalcanti, E.S.B., S.M. Morais, M.A.A. Lima, and E.W.P. Santana. 2004. Larvicidal activity of essential oils from Brazilian plants against Aedes aegypti L. Memorias do Instituto Oswaldo Cruz 99:541-544.

Daferera, D.J., B.N. Ziogas, and M.G. Polissiou. 2000. GC-MS analysis of essential oils from some Greek aromatic plants and their fungitoxicity on Penicillium digitatum. Journal of Agricultural and Food Chemistry 48:2576-2581. 
Epidi, T.T., C.D. Nwani, and S. Udoh. 2008. Efficacy of some plant species for the control of cowpea weevil (Callosobruchus maculatus) and maize weevil (Sitophilus zeamais). International Journal of Agricultural Biology 10:588-590.

Finney, D.J. 1971. Probit analysis. Cambridge University, London, UK.

Han, S.T. 1998. Medicinal plants in the South Pacific. World Health Organization (WHO) Regional Publications, Western Pacific Series $N^{\circ} 19.254$ p. WHO, Regional Office for Western Pacific, Manila, Philippines.

Intekhab, J., and M. Aslam. 2009. Isolation of a flavonoid from the roots of Citrus sinensis. Malaysian Journal of Pharmaceutical Sciences 7:1-8.

Isman, M.B. 2000. Plant essential oils for pest and disease management. Crop Protection 19:603-608.

Kucerova, Z., R. Aulicky, and V. Stejskal. 2003. Accumulation of pest-arthropods in grain residues found in an empty store. Z. Pflanzenkrankh. Pflanzenschutz. Journal of Plant Disease and Protection 110:499-504.

Lecato, G.L. 1976. Yield, development, and weight of Cadra cautella (Walker) and Plodia interpunctella (Hübner) on twenty-one diets derived from natural products. Journal of Stored Products Research 12:4347.

Mahfuz, I., and M. Khalequzzaman. 2007. Contact and fumigant toxicity of essential oils against Callosobruchus maculatus. University Journal of Zoology, Rajshahi University 26:63-66.

Mahmoudvand, M., M.H. Hosseinpour, H. Abbasipour, F. Rastegar, and M. Basij. 2011. Using some plant essential oils as natural fumigants against adults of Callosobruchus maculatus (F.) (Col: Bruchidae). Munis Entomology \& Zoology 6:150-154.

Marderosian, A.D. 2001. Peppermint. p. 465-466 In Der Marderosian, B. (ed.) The review of natural products. Facts and Comparisons, St. Louis, Missouri, USA.

Mozzaffarian, V. 1998. A dictionary of Iranian plant names. Farhang Moaser Publication, Tehran, Iran.

Omomouwajo, O.R., A.A. Gbolade, R. Nia, and F.B. Adewoyin. 2005. p. 72. The 11th Symposium of the Natural Product Research Network for Eastern and Central Africa (NAPRECA), Madagascar, Antananarivo. 9-12 August.
Prabakar, K., and A. Jebanesan. 2004. Larvicidal efficacy of some Cucurbitacious plant leaf extracts against Culex quinquefasciatus (Say). Bioresource Technology 95:113-114.

Prakash, A., and J. Rao. 1997. Botanical pesticides in agriculture. 461 p. CRC Press, Baton Rouge, Florida, USA.

Rajendran, S., and V. Sriranjini. 2008. Plant products as fumigants for stored-product insect control. Journal of Stored Products Research 44:126-135.

Rastegar, F., M. Mahmoudvand, and H. Abbasipour. 2010. Comparative study of insecticidal activity of essential oils of Zataria multiflora Boiss. (Lamiaceae) and Juniperus sabina (Cupressaceae) on Callosobruchus maculatus (F.) (Coleoptera: Bruchidae). 5th International Food Legumes Research Conference (IFLRC V) and 7th European Conference on Grain Legumes (AEP VII), Antalya, Turkey. 26-30 April. Akdeniz University, Antalya, Turkey.

SAS Institute. 1997. SAS/STAT guide for personal computers. Version 6.12. SAS Institute, Cary, North Carolina, USA.

Shaaya, E., M. Kostjukovski, J. Eilberg, and C. Sukprakarn. 1997. Plant oils as fumigants and contact insecticides for the control of stored-product insects. Journal of Stored Products Research 33:7-15.

Shojaaddini, M., S. Moharramipour, and B.Z. Sahaf. 2008. Fumigant toxicity of essential oil from Carum copticum against indian meal moth, Plodia interpunctella. Journal of Plant Protection Research 48: 411-419.

Simmons, P., and H.D. Nelson. 1975. Insects on dried fruits. USDA Agricultural Handbook 464. USDA, Washington DC, USA.

Zewde, D.K., and B. Jembere. 2010. Evaluation of orange peel Citrus sinensis (L.) as a source of repellent, toxicant and protectant against Zabrotes subfasciatus (Coleoptera: Bruchidae). Momona Ethiopian Journal of Science 2:61-75. 